\title{
地表プロセスと環境変動を測る 時間軸の設定
}

長谷部徳子

\section{1 ) はじめに}

地表を「地球の表層部」といった広い意味で はなく、陸域における固体地球と水圈・気圈の 境界部と捉えると、地表で観察されるプロセス として、固体地球に主たる原因を持つもの（例 えば火山の噴火や地震断層に起因する隆起・陥 没など）と、水圈・気圈の主要な構成物である 流体による固体地球の改変が挙げられる。マク ロな改変は地形の変化として現れる。流体によ る地形の変化は、流体の挙動が環境因子として 果たす役割の大きさを考えると、局所的・広域 的環境を反映するといってよい。固体地球部に 主たる原因を持つ地表プロセスも、水圈・気圈 と固体地球との相互作用を考えると（例えば噴 火による気圈へのガス・微粒子の放出や、山脈 形成による大気循環への影響など)、環境変動 を司る因子のひとつといってよく、このなかに も地形の変化を伴うものがある。現在観察され る地形の形成過程に時間軸をいれることは、地 形変化のプロセスの理解に必要であるととも に、その変化の要因が固体地球にあれ、流体と の相互作用にあれ、環境変動をはかる上で重要 な役割を果たす。

地形変化を一地点で考えると、基準面にたい して上方に変化する場合、下方に変化する場合、 変化がない場合の 3 通りがある。基準面を地表 にとれば、上方変化は物質の追加（堆積）によっ てもたらされ下方変化は物質の削除、すなわち
削剥によってもたらされる。したがって地形変 化をもたらすプロセスを大きく堆積と削剥の 2 つに大別し、それに変化を伴わない安定状態を 加え、それぞれのプロセスがいつ起こったのか 見積もる方法について紹介する。

\section{2）堆積年代の求め方}

堆積した「物」があるので、その「物」を利 用していろいろな手法が可能である。生物の化 石のなかでも、花粉や水生のプランクトン（珪 藻や有孔虫など）は、進化発達史が分かってい れば堆積時代を決めることができるだけでな く、その時代の環境の指標にもなるためよく利 用されている。また火山灰が挟まれているとそ の噴火の時期が分かっていれば年代が決まる。 堆積物の特徵が深度に対して周期的に変化す る場合、深度は時間のプロキシであるから、時 間軸が既に入っているものと同様な周期的な 変化が認められれば対照によって年代を入れ られることもある。

一方、堆積年代を数值で表そうとすると実は なかなか難しい。数值年代を得るためには放射 性元素の壊変を利用する。この壊変は放射性元 素があればいつでもどこでも営々と起こって いる現象である。この現象を利用して数值年代 を得る時には、分析する対象となる「物」が、 外界との元素のやり取りをしなくなって以降 どれくらいの量の放射性元素が壊変したかを 
見積もるのが一般的である。元素のやりとりを しなくなった状況を「閉鎖系となった」と表現 する。またこの閉鎖系が成立した「時」を「時 計が動き出した」などと表現する。堆積物の場 合、堆積するや否や「時計が動き出す」例は決 して多くなく、前述の火山灰と、堆積に巻き込 まれて死に至った生物の遺骸が、代表的な堆積 時に閉鎖系を実現させる物質である。火山灰は 含まれている鉱物次第でいろいろな放射性元 素を利用した年代決定が可能である。生物の遺

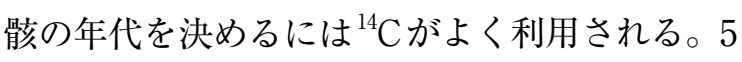
万年より新しい堆積物に利用可能である。

堆積性の放射性元素を利用する方法もある。 この場合堆積性放射性元素の初期量を見積も り、現存量との比較で堆積以後経過した時間を 求める。利用される放射性元素としては ${ }^{210} \mathrm{~Pb}$, ${ }^{10} \mathrm{Be},{ }^{26} \mathrm{Al}$ な゙が挙げられる。閉鎖系を保ってい ることが必須であるため、例えば圧密や堆積物 からの水の移動に伴い元素の移動が起こる場 合には利用できない。初期量の決定が難しいた め、多くは堆積物の深度方向への濃度変動や現 在堆積しつつある放射性元素の観測に基づき 初期量を仮定して年代を見積もる。

最近新たに利用されるようになった手法に ルミネッセンス年代測定法がある。これは堆積 物そのものを環境放射能の検出器ととらえ、堆 積物が浴びた環境放射能を一年あたりの環境 放射能と比較して年代を見積もる方法である。 当然堆積する時にそれまでに浴びていた放射 能による効果がリセットされていなければ堆
積年代をしめさない。ルミネッセンス年代測定 の面白いところは露光によってリセットされ ることである。したがって、試料の採取や室内 での分析実験の際に光を避ける必要があるの は苦労であるが、堆積年代を求めるには好都合 である。50年以上の歴史を持つ手法ではある が、実際に堆積物の年代決定に頻繁に利用され るようになったのは近年の環境問題への関心 の高まりに歩調を合わせ手法のポテンシャル が注目を集めるようになったここ 20 年くらい のことである。いまだ発展途上の手法でもあり、 基礎実験が活発に行われている。堆積プロセス のうち、カタストロフィックなイベントによっ て急激に堆積した物に対しては、堆積時の露光 が十分でないために年代測定ができないこと もある。

\section{3）削剥年代の求め方}

堆積場と異なり、削剥が起こる場所は「物」 が取り除かれる。削剥をもたらす営力は海水面 との差が大きいほど大きいため、地表面を基準 とした場合には削剥場では下方へ地形が変化 しているが、海水面など他の基準面から見ると 隆起のため上方へ地形が変化していることが あることがおもしろい。

削剥された物がどこに移動して堆積したの かが分かっている場合、その堆積物の堆積年 代によって削剥プロセスに年代を入れること が可能である。削剥プロセスそのものを相手に 
年代を見る場合は、熱年代学的な取り組みを 行う。削剥によって地下深くにあった物が表層 に近づくことは、地温により高温下にあった物 が地表に近づくにつれて温度が低下すること である。現在地表で得られる岩石が、どのよう な冷却を経たのかを調べる際には、放射年代測 定法の中でも比較的低温で時計が動き出す手 法が利用される。この時計が動き出す温度を閉 鎖温度という。表層のみならず、柱状試料を利 用できると、深度による年代值や熱履歴の違い からより詳細に削剥時期が特定できる（図1）。 フィッショントラック年代測定法、ウラン・ト リウムから放出されるアルファ線（ヘリウム原

図 1

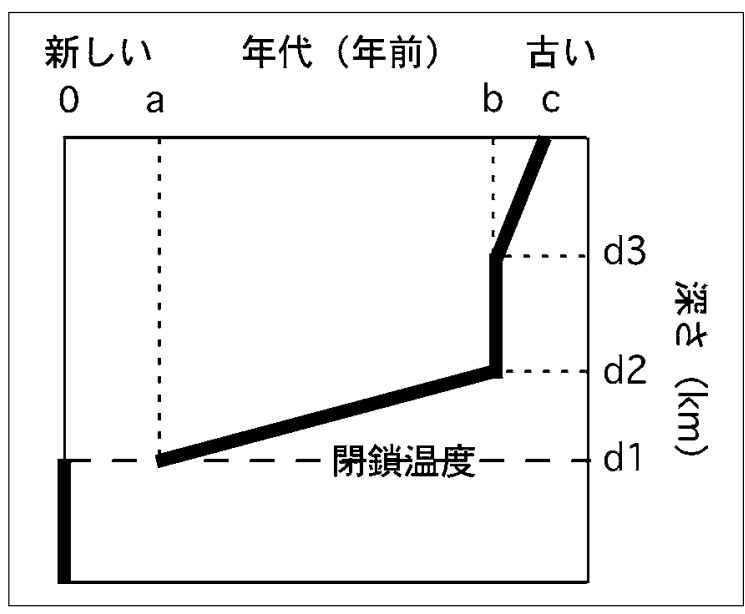

深度方向に図のような仮想的な熱年代を得た場合、以下 のように削剥プロセスを推定できる。d1の深さに対応す る地温が閉鎖温度であるとする。 $\mathrm{c}$ 時点から $\mathrm{b}$ 時点にか けては、削剥速度は $\frac{d 3}{c-b}(\mathrm{~km} /$ 年)、b 時点で一気に (d3 $-\mathrm{d} 2) \mathrm{km}$ 削剥され、 $\mathrm{b}$ 時点から $\mathrm{a}$ 時点にかけてはゆっく $り \frac{d 1-d 2}{b-a}(\mathrm{~km} /$ 年 $)$ 削剥される。a時点から現在にか けては、削剥はおこらず静穏な時代。

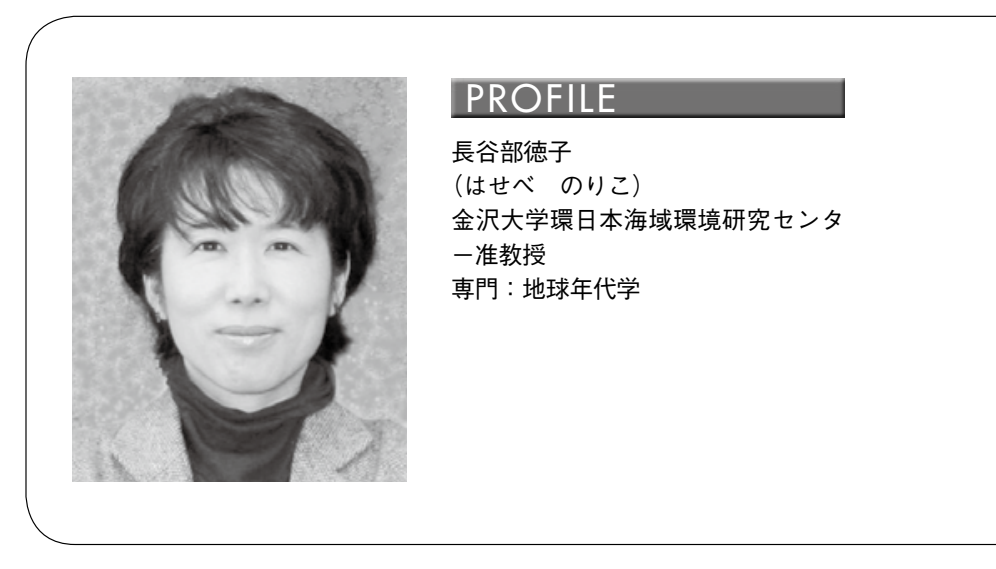

子）による年代測定法、Ar/Ar法が、熱履歴 を調べるのに利用される。これらの熱年代学的 手法を網羅した国際会議が二年ごとに開催さ れるが、日本では手法ごとのコミュニティはあ るものの、国際組織に対応するような手法横断 的な組織がないのは残念なことである。これら の手法は数千万年のタイムスケールを持つ地 形プロセス（例えばヒマラヤ山脈の形成による 削剥や大陸内にリフト带が形成されることに 伴うリフト帯縁辺部の上昇削剥など）に有効で あり、時間スケールの長い環境変動を見るのに は役に立つが、人類紀の環境変動解析にはやや その解像度に現状では不足があることも否め ない。

\section{4) 静穏期間の求め方}

堆積も削剥も被らない安定な期間も地表プ ロセスの重要な一側面である。どれくらいの期 間安定であったかを調べる直接的な手法とし ては宇宙線起源の同位体がどれくらいあるか を調べることによって試みられている。宇宙線 に起因して様々な核反応が招こり、ある同位体 
図2 宇宙線生成核種の量の概念図

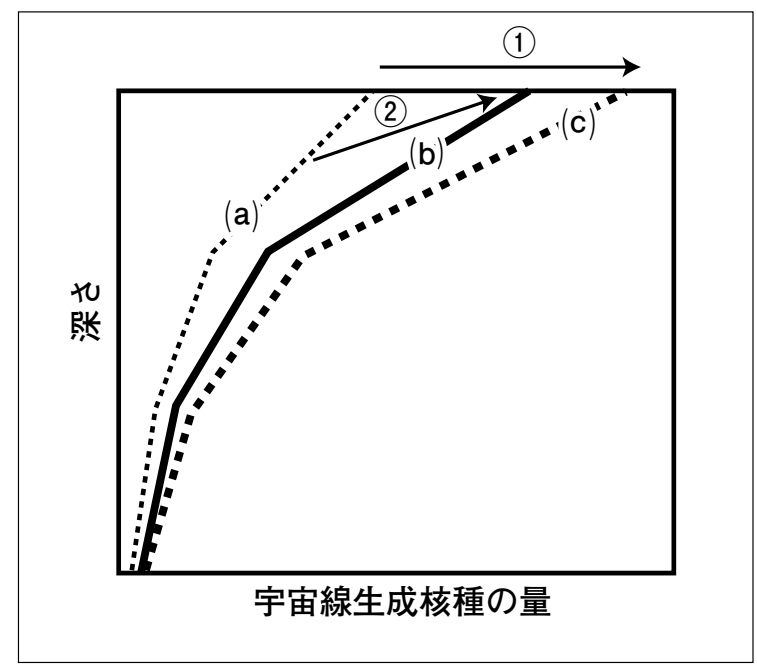

深さ方向に核種生成率が低下し点線（a）のように核種 が生成される。静穏な場所の場合、時間がたてば矢印 1 のように核種がさらに増加し点線（c）のようなプロファ イルが得られ、年代決定ができる。しかし削剥があった 場合、上方への移動と核種の増加によって矢印(2)のよう に值が変わり実線（b) のようになる。従って削剥がな いと思って年代を計算すると、年代值を若く見積もって しまう。異なる生成率を持つ宇宙線生成核種の分析結果 と比較すると年代值の不一致が生じるので、複数の核種 で削剥速度と表層年代が一致する組み合わせを見いだす ことによってプロセスを理解する。

は放射性同位体に変化する。一年間の放射性同 位体生成率を別途求め、表層試料にどれくらい それらの同位体が形成されているかを見積も ることにより表層が表層となって以降どれく らい時を経過したかを算出する（図2）。生成 率は地球磁場の変動や宇宙線量の変動により 時間変化するために見積もるのはかなり難し いようである。宇宙線は表層部にのみ降り注ぐ とはいうものの、透過力があるので深さ方向に 生成率が下がる。それらの放射性同位体は壊変
によって減少するので、生成と壊変の両方の効 果を考慮に入れ、な扮かつ深度方向に分析を行 うことで生成率の異なる場の情報を包括的に 説明できる安定期間を算出する。この手法は、 元々は隕石がどれくらいの期間宇宙空間を旅 してきたかを見積もることに利用されてきた。 しかし分析機器の発達によりごく微量の放射 性同位体の分析が可能になったことから、地球 表層部への応用が可能になった。

\section{5）おわりに}

以上地表プロセスのうち、地形変化に着目し て、3つに分けて年代軸を入れる方法を紹介し た。実際の「場」が堆積場なのか削剥場なの か、あるいは静穏な場所なのか判断が難しい場 合も多い。したがって上述の手法をいくつか組 み合わせて包括的に地形変化史を理解する。図 1の例のように削剥プロセスを理解するために 熱年代学的な手法を適用したところ、静穏期間 があることが明らかになることもある。また図 2 に示したように、静穏な場所だと考えて宇宙 線に起因する放射性核種をはかる場合に削剥 があったことが分かる例もある。従って多くの 場合は複合的に手法を駆使して地表プロセス に年代を入れていく。図1や図 2 に示した例は 単純かつ理想的な場合であるが、実際は分析誤 差や手法そのものの基礎的な理解が十分でな いなどの理由から、一筋縄の解釈ではいかない ことが多いのも事実である。 
ここで紹介した手法に興味がある方は、関連 の地球科学や考古科学の教科書にてさらに理 解を深めることができる。本稿ではふれなかっ たが、地形の変化を伴わない地表プロセスの年 代決定に応用できる手法も多い。

これら3つの内容については参考になる文献 を紹介して結びとする。

\section{参考文献}

ルミネッセンス年代測定と地形発達 : Geomorphology vol. 109, Special Issue on Application of Luminescence Dating in Geomorphology

熱年代学: Reviews in Mineralogy and Geochemistry vol. 58, Low-Temperature Thermochronology: Techniques, Interpretations, and Applications

宇宙線生成核種：Reviews in Mineralogy and Geochemistry vol. 47, p. 731-784, Cosmic-Ray-Produced Noble Gases in Terrestrial Rocks: Dating Tools for Surface Processes by Niedermann, S. 